\title{
Forest management planning in Newfoundland and Labrador: The Western Newfoundland Model Forest contribution
}

\author{
by Len Moores ${ }^{1}$ and Sean Dolter ${ }^{2}$
}

The management of forests has dramatically changed in the past few decades. Forest managers no longer can prepare and implement forest management plans in isolation of other resource values and local citizens. Today, the economic, ecological and social values are blended together into sustainable forest management. Finding a balance among these values in Newfoundland and Labrador is done through local district planning teams. The team participants need to understand the principles of sustainable forest management and the overall planning process. A primary focus of the Western Newfoundland Model Forest has been to support planning teams through the development of management tools to enhance management of the Province's forest ecosystems. The Model forest program will continue to test, document and transfer new and innovative management options to forest managers.

Key words: adaptive management, consensus, sustainable forest management, planning teams, public involvement, model forests

L'aménagement des forêts a dramatiquement change au cours des dernières décennies. Les aménagistes forestiers ne peuvent plus élaborer et implanter des plans d'aménagement forestier indépendamment des autres ressources et des citoyens locaux. De nos jours, les valeurs économiques, écologiques et sociales se sont amalgamées pour constituer l'aménagement forestier durable. L'équilibre entre ces valeurs à Terre-Neuve et au Labrador s'effectue par l'entremise des équipes locales de planification des districts. Les participants au sein des équipes doivent comprendre les principes de l'aménagement forestier durable et l'ensemble du processus de planification. L'attention principale de la Forêt modèle de l'ouest de Terre-Neuve a été d'appuyer les équipes de planification au moyen de l'élaboration d'outils d'aménagement pour accroître l'aménagement des écosystèmes forestiers de la province. Le programme de la forêt modèle continuera de tester, de documenter et de transférer les nouvelles options innovatrices aux aménagistes forestiers.

Mots-clés: aménagement adapté, consensus, aménagement forestier durable, équipes de planification, participation du public, forêts modèles

\section{Introduction}

The forest ecosystems of Newfoundland and Labrador are valued by the people of the province for a variety of reasons. For example, the forests provide many recreational opportunities ranging from fishing, hunting, trapping, hiking, birdwatching and berry picking, to supplying timber for domestic and commercial purposes. Historically, these values were planned in isolation of each other, resulting in conflicts between competing uses. However, today, the economic, ecological and social values are blended together into sustainable forest management. Finding a balance among these values in Newfoundland and Labrador is done through local district planning teams and documented in the district forest management plans.

District planning teams use a consensus decision-making process when making decisions pertaining to district forest ecosystem strategy documents and five-year operating plans. Each individual on a planning team has different values and perceptions of their local forests. Planning team participants struggle with these values when they compete with each other. The willingness to compromise our individual values/perceptions and the willingness to learn is necessary to the success of the process, the preparation of plans and, ultimately, management of local forests.

${ }^{1}$ Newfoundland Forest Service, Department of Forest Resources and Agrifoods, P.O. Box 2006, Corner Brook, Newfoundland A2H 6J8. E-mail: lmoores@mail.gov.nf.ca

${ }^{2}$ Western Newfoundland Model Forest

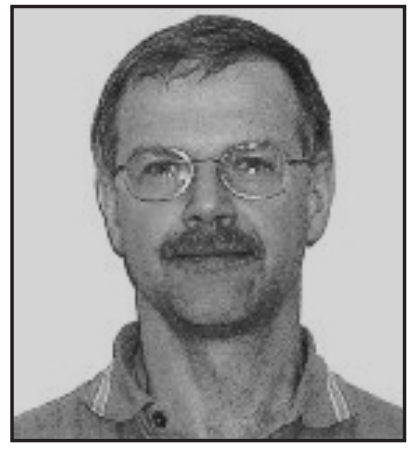

Len Moores

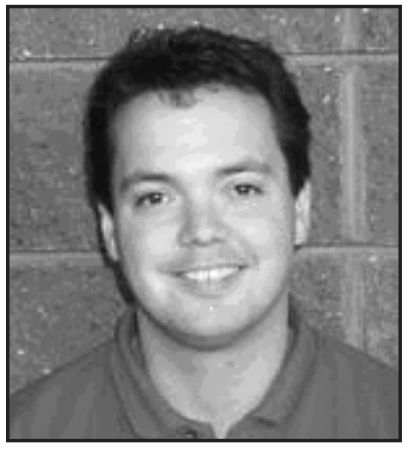

Sean Dolter

\section{Planning Framework}

Forests ecosystems in the province are managed at the forest management district level. Each management district has a forest management plan which is comprised of three documents:

1. Twenty-year management plan report (commonly referred to as the forest ecosystem strategy document). This report establishes the values, goals, indicators, objectives and strategies for managing the forest ecosystems of the district. A biophysical description of the district, the problems associated with attaining a regulated forest, and the policies and practices to attain a regulated forest are also described in the plan.

2. Five-year operating plan. This plan details how forest management activities (timber harvesting, planting, tree thinning 
and road construction) will be implemented as per the strategies of the forest ecosystem strategy document.

3. Annual operating plan. A detailed plan prepared every year that describes exactly where forestry activity will occur in a particular year.

\section{Western Newfoundland Model Forest Contributions}

The Western Newfoundland Model Forest (WNMF) program was initiated in 1992. A primary focus of this program has been to support and develop management tools to enhance management of the province's forest ecosystems. In Phase One, the Western Newfoundland Model Forest Inc. (WNMF) partnership composed an Integrated Resource Management document that described the essential elements of ten different forest value groups. Included in these groups were water systems, timber, recreation and tourism, fish and habitat, wildlife and habitat, intrinsic and intangible values, mines/energy, and agricultural resources, protected areas, and ecosystem health.

Under these values, management objectives were set and agreed upon by the model forest partnership. As a result of this process, the WNMF brought together key resource managers from the forestry community to discuss forest management with recreational groups, outfitters, tourism operators, naturalists and environmentalists. In some cases, these interactions were for the first time. These relationships set the foundation for today's sustainable resource management partnerships.

Phase Two of the WNMF program involved the implementation of the above-mentioned values into the daily practices of the partnership. The WNMF also contributed to the provincial forest management planning process and preparation of district forest management plans. This contribution involved the development of the following management tools:

1. The Criteria and Indicators initiative began for the WNMF in 1997. From its extensive experience with ten forest value groups from Phase One's Integrated Resource Management (IRM) approach, it was a fairly easy for the WNMF transition to adopt the CCFM framework. Adoption of the framework resulted in a progressive approach to further refining the values, goals, indicators, and practices of sustainable forest management (SFM) for the province. The implementation of the criteria and indicator framework has been championed by the Newfoundland Forest Service (NFS) in most of the districts in Newfoundland.

2. Pioneering the need and value of ground rules and consensus decision-making in multi- stakeholder planning processes. The WNMF continued to demonstrate that a partnership comprising diverse interests could make decisions by consensus and how ground rules are necessary to direct a multistakeholder process. A joint effort between the WNMF partnership and the NFS produced a booklet on ground rules that each planning team formally adopts in its entirety or with slight modifications. Even though this booklet assists tremendously with preparing each member of the planning team for the upcoming negotiations, consensus is still a challenge for planning teams and to the individuals that facilitate these processes.

3. Modifying and documenting different approaches to the planning process and plans. Presently, every planning team within the province is approaching district planning with a slightly different process structure. This freedom has favoured the involvement of the public and resource agencies in some cases and deterred them from participating in others. Scheduled presentations on virtually every aspect of forest management does not guarantee meaningful involvement. Planning teams needed to focus on strategic and operational conflicts in relation to each defined value and design their plans for solutions to the conflicts. The Labrador planning team and the WNMF partnership designed similar frameworks for structuring meetings that strategically involves appropriate representation of values at each meeting when warranted. The framework divided meetings into four categories:

Process Meetings: The process needs to be defined for each and every planning team member. These meetings usually kick off and end the provincial planning process. Issues discussed at these meetings include establishing ground rules, conditions of consensus, methods of resolution, time and location of meetings, reimbursement of expenses, topics to be engaged, questions to be answered per topic, speakers or guests per topic, internal and external communication (frequency, format , and mechanism), sub-processes for negotiation and resolution (time limits and outside mediation) and facilitation. Value Meetings: The crucial discussion at the district planning level is about ecological and human values. It is acknowledged that not every value can be addressed and priority must be placed on those values that are particularly worthy of discussion. Two levels of discussion take place per value meeting. The "Strategic Level" characterizes the value and identifies the critical forest elements, and existing guiding principles or policies that maintain the critical elements necessary to preserve the integrity of the value in question. "Operational Level" planning is used to discuss the spatial layout of value, conflicts with harvesting, and resolutions to these conflicts. When inviting outside expertise to value meetings to contribute to the team's knowledge on a specific value, it became necessary to offer a guideline to presenters. This guideline minimizes the introduction of elements that cannot be resolved by the planning teams and are irrelevant to the discussions. This method improved the effectiveness of every presentation and was welcomed by the presenters.

Knowledge-based Workshops: Any process dealing with the level of knowledge necessary for decision-making needs to incorporate opportunities for learning. The process provides the opportunity for external learning workshops to form at the request of the planning team. Process-specific workshops deal with issues such as, but not limited to, Annual Allowable Cut, Criteria and Indicators, and Socio-economic Analysis.

Plenary Meetings: One of most important aspects of planning is characterizing what has been recorded and potentially presented as the output of the discussions. A structured review, which takes approximately three meetings, discusses the strategic and operational conclusions per value, the contested issues, and the statements of support or dispute (Gradients of Consensus).

4. Integrating the methodology for community surveying and spatial referencing non-timber values. A project of the WNMF, "Geo-referencing Non-Timber Values in Management Planning" (Pilot Project 2002: District 15) improved the planning team's ability to spatially determine future conflicts with 
recreation, tourism, outfitting, subsistence values, and other non-timber interactions with the forest. The WNMF has now produced two manuals on the process: a manual for planning teams that explains how to collect this information, and a manual for the GIS Technician for integrating the information into the ARCInfo system.

5. Documenting methodologies applied to resolve conflicts regarding aesthetics and buffer zones. WNMF has accepted the role of recording the experiences of its partnership and translating those experiences into a format that transfers the learning that occurred to other locations and organizations involved in management planning. When aesthetics have been an issue of conflict at the planning team level, methodologies for resolving the conflict need to be shared. For example, a project of Corner Brook Pulp and Paper Limited (CBPPL) was to establish a small working group comprised of a local outfitter and resource professionals and task them with the development of a landscape design concept for a tributary area off the Main River (Upper Main River: Forest Landscape Design, Simon Bell, CBPPL, 1998). The first phase of this concept design was later implemented by the Woodlands Department of CBPPL and documented by the WNMF for the benefit of other forest managers in need of management techniques to address conflicts surrounding aesthetics. Three documents were produced through WNMF's relationship with CBPPL: Landscape Design Project Report, Landscape Design Manual, and GEO III: GPS Manual for Landscape Design (http://www.wnmf.com under "What's New").

6. Defining the research protocols for socio-economic valuation at the district level. As a project initiated in the final year of Phase Two (1997-2002), socio-economic valuation is being approached at a district level by the WNMF partnership involving the NFS, CBPPL, Abitibi-Consolidated of Canada, Sir Wilfred Grenville College and Gros Morne National Park. Sir Wilfred Grenfell College of Memorial University is in the process of developing a research protocol for district teams to engage in socio-economic analysis. In year 2002-2003, District 16 will be used as the first pilot of this proposed protocol. If successful in meeting the needs of district teams, the WNMF will produce district applicable manuals for conducting similar processes throughout Newfoundland and Labrador. This approach will also be evaluated for its applicability to other model forest sites across Canada.

7. Increasing the capacity for public participation using the Internet by integrating Web-based formatting into the writing of district plans. A major challenge for district team members is access to available information and the costs associated with hard-copy reproductions. The WNMF assisted in the development of a Web-based Strategic Plan for Forest Management District 16 in 2001-2002. The NFS now has a district-by-district Web site dedicated to the hosting of dis- trict agendas, minutes, and draft plans. The WNMF has future interest in building the capacity of each team to publish their plans in a format that can be easily accessed by a wide range of planning team members. Templates for plan development, map libraries, and interactive value-oriented chat rooms will be some of many products in development over the next phase of the model forest.

\section{Future Initiatives to Support Planning}

The third phase of the model forest program will see the WNMF and the NFS partnership continue to flourish in designing initiatives to support forest management. These initiates will focus on an array of issues, but not limited to:

1. Review of forest management planning frameworks across Canada. The NFS and other model forest partners are interested in other forest management planning processes and how the provincial process can be improved.

2. Biodiversity assessment tools and defining natural disturbance regimes for the province. Provincial wood supply analysis includes the forecast of future forest conditions. Biodiversity assessment tools are being developed to assess these forecasts in terms of forest biodiversity. The natural disturbance regimes for the province are to be defined as part of this program.

3. Socio-economic assessment at a management district level. Planning team participants are continually seeking an economic understanding of all values and their influence on the people of the district. A socio-economic analysis protocol will be developed to enable forest managers to conduct and understand some form of local socio-economic analysis.

4. Measuring indicators. During the past five year period, a multitude of indicators has been developed on various aspects of SFM. A major challenge in the province will be to collect the necessary data, interpret and report. The WNMF partnership will work toward methodologies to measure the ecological, economic and social indicators.

5. Aboriginal partnerships in Labrador. Innu Nation and the NFS have asked the WNMF to facilitate a forest management committee (FMC) whose responsibility is the implementation of the five-year operating plan for District 19a.

\section{Conclusions}

As society continues to increase its demands from the forest, conflicts between its values and mitigating the impacts between forest values and timber management will be a challenge. New management tools need to be explored and learning experiences shared with those involved in managing forests. During the past ten years the WNMF and its partners have tested new management concepts. The role of the WNMF has been to test, document and transfer to managers innovative management skills. 